https://doi.org/10.30910/turkjans.740195

\begin{tabular}{c}
\hline TÜRK \\
TARIM ve DOĞA BiLIMLERI \\
DERGISI \\
\hline \hline
\end{tabular}

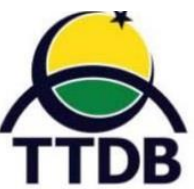

www.dergipark.gov.tr/turkjans

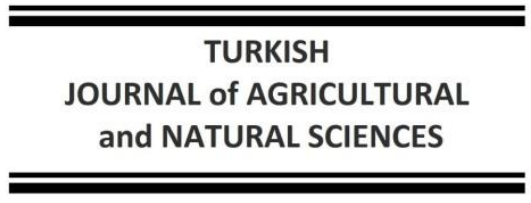

Research Article

\title{
Occurrence of Cucumber mosaic cucumovirus and Watermelon mosaic potyvirus on Melon exhibiting viral symptoms in Bingöl province of Turkey and Their Phylogenetic Affinities
}

\author{
${ }^{1}$ Abdullah GÜLLER*, ${ }^{2}$ Mustafa USTA \\ ${ }^{1}$ Bingöl University, Faculty of Agriculture, Department of Plant Protection, Bingol \\ ${ }^{2}$ Van Yüzüncü Yıl University, Faculty of Agriculture, Department of Plant Protection, Van \\ *Corresponding Author: aguller@bingol.edu.tr
}

\section{Geliş Tarihi: 20.05.2020 Düzeltme Geliş Tarihi: 07.10.2020 Kabul Tarihi: 12.10.2020}

\begin{abstract}
In the surveys conducted in the province of Bingöl in 2019, melon plants exhibiting foliar deformations, mosaic pattern in different concentrations of green, and vein banding were noticed. Melon specimens were gathered and screened by RT-PCR using capsid protein (CP) gene-specific primer sets to characterize and to ascertain the possible viral agents related to infected plants. About 657 bp and 822 bp DNA fragments were observed in the agarose gel of infected plants, confirming the presence of Cucumber mosaic cucumovirus (CMV) and Watermelon mosaic potyvirus (WMV). Two related DNA fragments from each recovered from agarose gel randomly were cloned in the proper cloning vector and sequenced by nextgeneration sequencing (NGS). Viral CP sequences obtained were deposited in GenBank (NCBI) with accession number MT361015 and MT361016 for CMV and with accession number MT413451 and 437295 for WMV. Sequences analysis revealed that CMV and WMV isolates showed high sequence consensus with their same species, 99.84\%, and 99.88\%, respectively. Further analysis disclosed that both Bingöl isolates showed the highest sequence similarity with China isolate (DQ399708). The consensus tree created from various CP sequences in different geographies clearly revealed that the two CMV isolates detected in this study are Subgroup IB, in the very close phylogenetic relations with Turkey, Thailand, India, and China's Subgroup IB isolates from diverse plant origins. Moreover, Bingöl WMV isolates exhibited an evolutionary affinity with isolates from melon and zucchini in France and isolate from a watermelon in China. This work is the first scientific evidence showing infection of CMV and WMV of melon plants in Bingöl province of Turkey, supported by high sequence homology and consensus trees.
\end{abstract}

Keywords: CMV, Capsid gene, Phylogenetic analysis, RT-PCR, WMV

\section{Türkiye'nin Bingöl ilinde Virüs Belirtisi Gösteren Kavun Bitkilerinde Hıyar mozaik virüsü ve Karpuz mozaik virüsünün Varlığı ve Filogenetik Yakınlıkları}

\section{Öz}

Bingöl ilinde 2019 yılında yapılan surveylerde yapraklarda deformasyon, yeşil rengin farklı tonlarında mozaik deseni ve damar bantlaşması sergileyen kavun bitkileri tespit edilmiştir. Örnekler toplanmış ve infekteli bitkilerdeki olası viral etmeni tanımlamak ve karakterize etmek için kapsid protein genine (CP) spesifik primer setleri kullanılarak RT-PCR ile taranmıştır. İnfekte bitkilerden elde edilen agaroz jelde gözlenen yaklaşık 657 bp ve 822 bp uzunluğundaki DNA fragmentleri Hıyar mozaik virüsü ve Karpuz mozaik virüsünün varlığını doğrulamıştır. Her bir virüs için rastgele seçilen iki DNA fragmenti jelden temizlenerek uygun klonlama vektörü içinde klonlanmış ve yeni nesil sekanslama (NGS) ile dizilenmiştir. Elde edilen viral CP sekansları, CMV için MT361015 ve MT361016 erişim numarasıyla ve WMV için MT413451 ve 437295 erişim numarasıyla gen bankasına (NCBI) kaydedilmiştir. Sekans analizi, CMV ve WMV izolatlarının sırasıyla\% 99.84 ve\% 99.88 ile aynı türleriyle yüksek oranda dizi konsensüsü gösterdiğini ortaya koymuştur. Daha ileri analizler, her iki Bingöl izolatının da Çin izolatıyla (DQ399708) en yüksek sekans benzerliği gösterdiğini ortaya çıkarmıştır. Farklı 
coğrafyalarda çeşitli CP sekanslarından oluşturulan konsensüs ağacı, bu çalışmada tespit edilen iki CMV izolatının çeşitli bitki kaynaklarından elde edilen Türkiye, Tayland, Hindistan ve Çin'in alt grup IB izolatları ile çok yakın filogenetik ilişkide olduğunu açıkça ortaya koymuştur. Ayrıca Bingöl WMV izolatları, kavun ve kabaktan elde edilen Fransa izolatlarıyla ve karpuzdan elde edilen Çin izolatıyla evrimsel bir yakınlık sergilemiştir. Bu çalışma, Bingöl ilindeki kavun bitkilerinde CMV ve WMV infeksiyonunu gösteren ve yüksek dizi homolojisi ile konsensüs ağacı ile desteklenen ilk bilimsel kanıttır.

Anahtar kelimeler: CMV, Filogenetik analiz, Kapsid geni, RT-PCR, WMV

\section{Introduction}

Cucurbit crops including melon, watermelon, cucumber, pumpkin belong to the Cucurbitaceae family, which contains about 119 genera and 825 species (Andres, 2004; Günay, 1993). Melon, an Asian origin cultivated plant, has been grown in a vast geographic region since 2000 $\mathrm{BC}$ and known by various synonym names including cantaloupe, muskmelon, winter melon, and casaba (Robinson and Decker-Walters, 1997; Nayar and Singh, 1998;). The global production of the melon (Cucumis melo L. ) is 52 million tons. Turkey has an important place in cucurbit-growing countries. According to the world melon production data of 2016, China takes the first place with 16009584 tons and Turkey ranks second with 1854356 tons from 786632 ha (FAO, 2018). Among cucurbits, melon is the second most-produced species, following watermelon in our country (Çat et al., 2016). The percentages of melon-producing regions are as follows: central Anatolia (41\%), Aegean (27\%), Southeast Anatolia (15\%), Mediterranean (7\%), Marmara with (5\%), Eastern Anatolia with (4\%), and Black Sea (1\%) (Şensoy, 2005). Melon can be subjected by most pathogens and pests. Many viral agents that seriously threaten Cucurbitaceae family cause crop losses of up to $100 \%$ (Coutts et al., 2011a). More than 35 known viruses have been recorded in this family. CMV (Cucumovirus), Zucchini yellow mosaic virus (ZYMV, Potyvirus), WMV (Potyvirus), and Squash mosaic virus (SqMV, Comovirus) are the most prevalent infecting cucurbits worldwide (Zitter et al., 1996). Some with limited distribution are Cucumber green mottle mosaic virus (CGMMV, Tobamovirus) (Nematollahi et al. 2004), Melon necrotic spot virus (MNSV, Gammacarmovirus) (Kwak et al., 2015), Tobacco ringspot virus (TRSV, Nepovirus) (Abdalla et al., 2012), Tomato ringspot virus (ToRSV, Nepovirus) (Jossey and Babadoost, 2008), Zucchini yellow fleck virus (ZYFV, Potyvirus) (Tomassoli et al., 2009).

With approximately 1000 natural hosts, CMV is a pathogen associated with agronomical losses especially infecting on cucurbits, which was first described by Doolittle in the USA and isolated for the first time in 1934 by Price (Doolittle, 1916; Price, 1934). The positive-sense single-strand viral RNA genome (+SsRNA) is tripartite, consisting of three genomic RNAs (RNA-1, RNA-2, RNA-3) and a subgenomic RNA (sgRNA-4) (Lot and Kaper, 1976). So far, two major groups have been defined as Groupl and Groupll, based on the serological data, hybridization and the amino acid map of the CP gene (Palukaitis et al., 1992).

Viral distribution occurs primarily via aphids in non-persistent mode, plus mechanically, humans, parasitic vector plants, and seeds of many cucurbit crops like squash, watermelon, melon, pumpkin (Tobias et al., 2008). The virus affect prominently the foliar morphology including mosaic pattern, blistering, vascular banding, and severe malformation and death in those heavily infected (Van Regenmortel et al., 2000).

WMV, which is widespread especially in temperate climates and Mediterranean countries, was first reported by Webb and Scott in watermelon (Citrullus lanatus) in Rio Grande Valley (Webb and Scoot, 1965) and then recorded in cucurbits plants from distinct geographic regions (Gibbs et al., 2008; Alonso-Prados et al., 2003). Crop losses induced by WMV can reach up to $100 \%$ depending on the season (Demski and Chalkley, 1972). The virus is a pathogen for more than 170 plant species in 27 families, including mostly Cucurbitaceae, Fabaceae, Malvaceae, and Chenopodiaceae.

Like CMV, WMV is also insect-borne and transmitted by 38 aphid species such as Aphis citricola, Myzus persicae, Aphis craccivora (Desbiez et al., 2007; Purcifull et al., 1984). Based on the host and serological features, WMV isolates are divided into two groups, namely WMV type 1 and WMV type 2 (Webb and Scott, 1965). While WMV1 isolate is specifically pathogenic for noncucurbitaceae family, WMV2 type is for cucurbitaceous plants. WMV1 was later considered as a strain of Papaya ringspot virus (PRSV) (Yeh et al., 1984; Purcifull and Hiebert, 1979). It mostly produces symptoms such as moderate to severe stunting, leaf deformation, blisters onto the leaf, dark green lines along the middle vein, interveinal chlorotic, or light green mottling (Delmiglio and Pearson, 2006; Brunt et al., 1996). 
Although much research has been the focus on the infection incidence and presence of CMV and WMV on cucurbits in Turkey, it has not been examined largely at the molecular level. Hence, this study has focused on the analysis of the CP gene and phylogenetic relationship of WMV and CMV deriving from a naturally diseased melon plant in Bingöl province using molecular techniques.

\section{Material and Method}

\section{Virus source and Total RNA (TNA) extraction}

In 2019, twelve suspicious leave specimens as total RNA sources were gathered from melon plants grown from mercantile areas, along with non-symptomatic (probably healthy) for comparative purposes in Bingöl-Turkey. RNAenriched TNA solutions were obtained according to the methodology formerly defined by Foissac et al. (2001). Obtained RNAs were stored at $-80^{\circ} \mathrm{C}$ until the cDNA process.

\section{Viral detection by molecular methods}

Viral detection was examined by complementary DNA synthesis (cDNA) and Reverse Transcription Polymerase Chain reaction (RT-PCR) assay, successively. The obtained RNAs of the test viruses were used as a template for the cDNA synthesis. The oligonucleotide primers used for both processes were designed according to the CP gene, with references below (Table 1).

The cDNA synthesis was carried out in two rounds for both pathogens. For the first round, $12 \mu \mathrm{l}$ reaction mixture, which is kept at $65{ }^{\circ} \mathrm{C}$ for $5 \mathrm{~min}$, contains the following components: RNA $(2 \mu \mathrm{l})$, dNTP mix $(1 \mu l)$, reverse primer $(1 \mu l)$ (listed below), and RNase free water $(8 \mu \mathrm{l})$. After incubating on ice for $5 \mathrm{~min}$, the second round consisted of 5X RT buffer $(4 \mu \mathrm{l}), 0.1 \mathrm{M}$ DTT $(2 \mu \mathrm{l})$, RNase-free water $(1 \mu \mathrm{l})$, and RT enzyme $(1 \mu \mathrm{l})$ in 8 $\mu$ volume for $45 \mathrm{~min}$ at $42{ }^{\circ} \mathrm{C}$, following by the reaction was terminated for $15 \mathrm{~min}$ at $70{ }^{\circ} \mathrm{C}$. A total of $20 \mu \mathrm{l} \mathrm{cDNAs}$ were stored at $-80^{\circ} \mathrm{C}$ for the next steps.

Table 1. Primer sets used based on the CP gene for CMV and WMV used in this study

\begin{tabular}{lllll}
\hline Primers & Upstream & Downstream & References & Size \\
\hline CMV & ATGGACAAATCTGAATCAAC & TCAGACTGGGAGCACTCCAG & Günay, 2019 & 657 bp \\
WMV & GAATCAGTGTCTCTGCAATCAGG & ATTCACGTCCCTTGCAGTGTG & Sharifi et al., 2008 & 822 bp \\
\hline
\end{tabular}

The resulted cDNAs were used as a template for the RT-PCR assay. The $25 \mu$ l of PCRmix consisted of $3 \mu \mathrm{l}$ of cDNA plus $15.6 \mu \mathrm{l}$ nucleasefree water, $1.5 \mu \mathrm{l}$ of $\mathrm{MgCl} 2,0.5 \mu \mathrm{l}$ of dNTPs, $0.5 \mu \mathrm{l}$ of both primers, $2.5 \mu \mathrm{l}$ of $10 \mathrm{X}$ Taq buffer, $0.4 \mu \mathrm{l}$ of Dream Taq DNA polymerase. The PCR apparatus (Thermo) for WMV was adjusted for $3 \mathrm{~min}$ at $94{ }^{\circ} \mathrm{C}$ (first denaturation), then 36 cycles of the $1 \mathrm{~min}$ at $94{ }^{\circ} \mathrm{C}$ (for $30 \mathrm{~s}$ for CMV) (denaturation), $60 \mathrm{~s}$ at $60^{\circ} \mathrm{C}$ (at $50^{\circ} \mathrm{C}$ for $\mathrm{CMV}$ ) (annealing), $60 \mathrm{~s}$ at $72^{\circ} \mathrm{C}$ (extension), followed by $72{ }^{\circ} \mathrm{C}$ at $5 \mathrm{~min}$ (last extension).

The reaction amplicons $(15 \mu l)$ and standard marker (1 kb, Thermo) were run in agarose gel (1.5\%) containing EtBr (1\%) within 1×TAE Buffer by electrical current (for $45 \mathrm{~min}$ at 90V) (Bio-Rad), and photographed by visualizing in UV light transilluminator. CMV (Günay, 2019) and WMV (Usta et al., 2018) isolates obtained from early studies were used as a positive control to confirm the PCR tests. Melon specimens without symptoms were also used as a negative control.
Sequencing, BLAST, and phylogenetic analysis Both sequences amplified in RT-PCR primed with related primer sets were cloned in $E$. coli using the prokaryotic cloning vector (pGEM TEasy) (Promega). Recombinant DNA fragments were sequenced by NGS (Sentebiolab/Ankara/Turkey) and recovered sequences were deposited in the NCBI database. Then, sequences related to Bingöl were checked by a BLAST nucleotide search (BLASTn) of the NCBI web site.

The consensus tree encompassing 18 individual sequences of $\mathrm{WMV}$ and $\mathrm{CMV} \mathrm{IA}, \mathrm{IB}$, and II groups were generated by CLC Main Workbench 6.7.1 software using Neighbor-Joining methodology (NJM) by 100 bootstrap score. FJ376388 (Soybean mosaic virus) and EF153735 (Tomato aspermy virus) are assigned as out-source for WMV and CMV, respectively. Multiple alignments and sequence identity of $\mathrm{CP}$ gene sequences of both agents were evaluated using the same program. 


\section{Results and Discussion}

Cucurbits are extensively infected by numerous viral pathogens. Damage caused by viruses varies between $50-100 \%$ depending on plant species, virus strain, vector density, and environmental situations (Raccah, 1999; Kaya and Erkan, 2011). These viruses had the opportunity to make an epidemic in vegetable-planting regions worldwide as one or a mixed infection with two or more viruses. In the present study, WMV and CMV retrieved from a naturally symptomatic melon and phylogenetic relationship of their $C P$ gene sequences were examined. DNA fragments of 822 bp in 5 specimens and $657 \mathrm{bp}$ in 6 specimens were obtained using PCR-based methods, indicating the presence of WMV and CMV, respectively. No amplification was monitored from melons without symptoms (Fig 2). As shown in Fig 1, the Bingöl plant samples exhibited the viral symptoms involving vascular banding, mosaic to yellowish from greenish, superficial mottling, and leaf deformation. These findings are in agreement with the symptoms reported in melon from other countries. (Katul and Makkouk, 1987; Tobias and Tulipan, 2002).
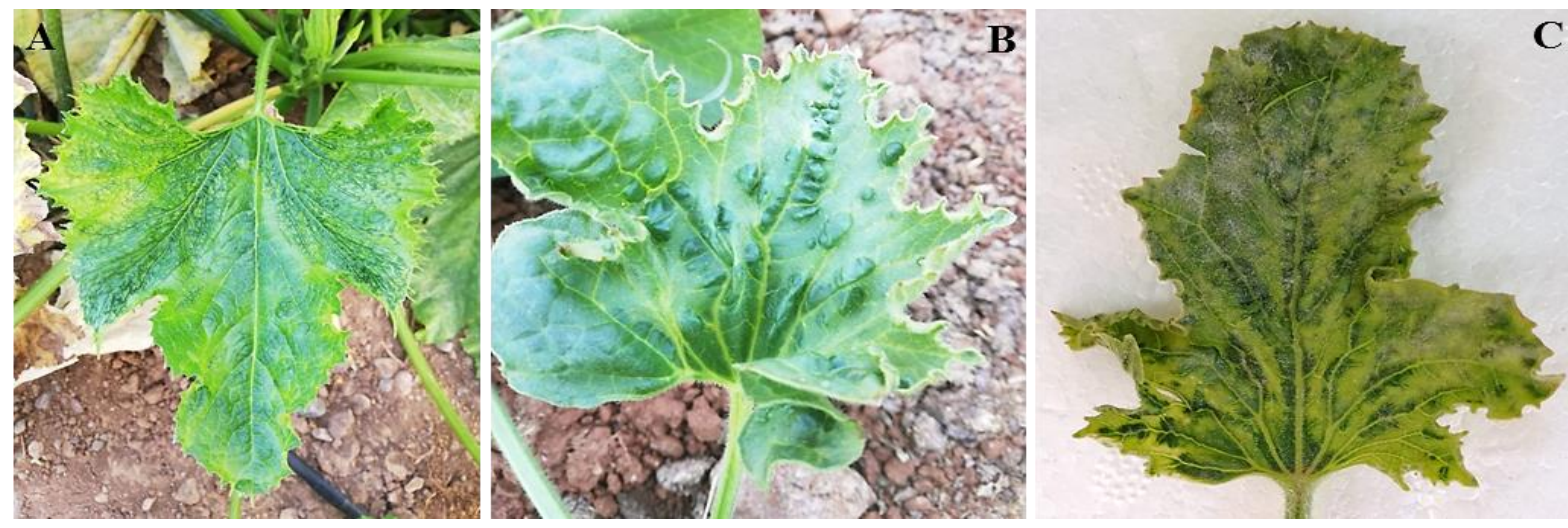

Figure 1. Viral disease symptoms in infected melon induced by WMV and CMV isolates A: Vein banding symptom and saw-like leaf edges, B: leaf distortion, rugosity, greenish mottle in leave and C: Green patched areas on the leaf.
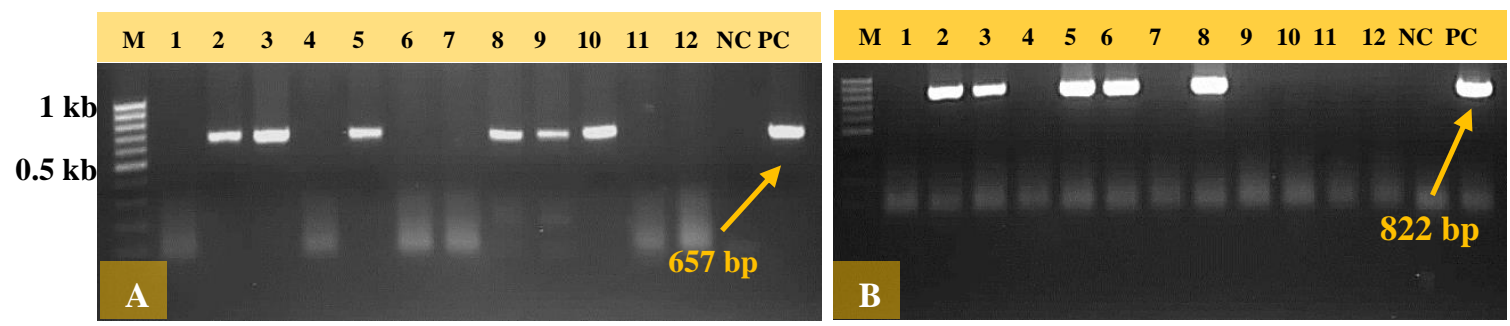

Figure 2. Agarose gel image obtained by electrophoresis of RT-PCR amplicons ( $15 \mu \mathrm{l})$ primed with CP specific primers for melon specimens collected from Bingöl province. Panel A and Panel B are agarose gel images obtained for CMV and WMV, respectively. Bright-looking DNA fragments represent viruspositive specimens. M: 1 kb ladder (Fermentas); PC: Positive control, NC: Negative control.

$\mathrm{CMV}$ is common on almost all continents involving Asia, Europe, Africa, North America, and Australia (Palukaitis and Garcia-Arenal, 2003). As in our study, their separately single or mixed infections have commonly been reported at with varying incidences of infection incidences in various plants in many countries. These include: Cyprus (Karamanlı and Kamberoğlu, 2010), USA (Fernandes et al., 1991), South Korea (Ko et al., 2007), Bosnia and Herzegovina (Trkulja et al., 2013), Taiwan (Hseu et al., 1987), Malaysia
(Fujisawa et al., 1990), Mexico (Aguliar-Rios and Lozoya-Saldana, 1994), Saudi Arabia (Al-Saleh and Al-Shahwan, 1997), Japan (Kosaka ve Fukunishi, 1997), Brazil (Silveria et al., 2009), South Africa (Ibaba et al., 2015), Australia (Coutts and Jones, 2005), Iran (Massumi et al., 2007), Italy (RubiesAutonell et al., 1996), Tunisia (Mnari-Hattab et al., 2008), Nigeria (Ayo-John et al., 2014).

As shown Fig 3, CMV has a wide range of distribution in Turkey's ecosystem and has a broad plant-host line including tobacco, Polygala 
myrtifolia, bean and spinach, pepper, tomato, cucumber, olive, and others (Beler and Açıkgöz, 2005; Çulal Kılıç and Yardımcı, 2012; Ergün et al., 2013; Erkan et al., 2013; Gökdağ et al., 2016;
Güngör et al., 2017; Gümüş et al., 2004; Karanfil and Korkmaz, 2017; Karanfil et al., 2016; Sevik and Akcura, 2011; Sevik, 2012; 2017; Sertkaya, 2015, Uzunoğulları and Gümüş, 2015).

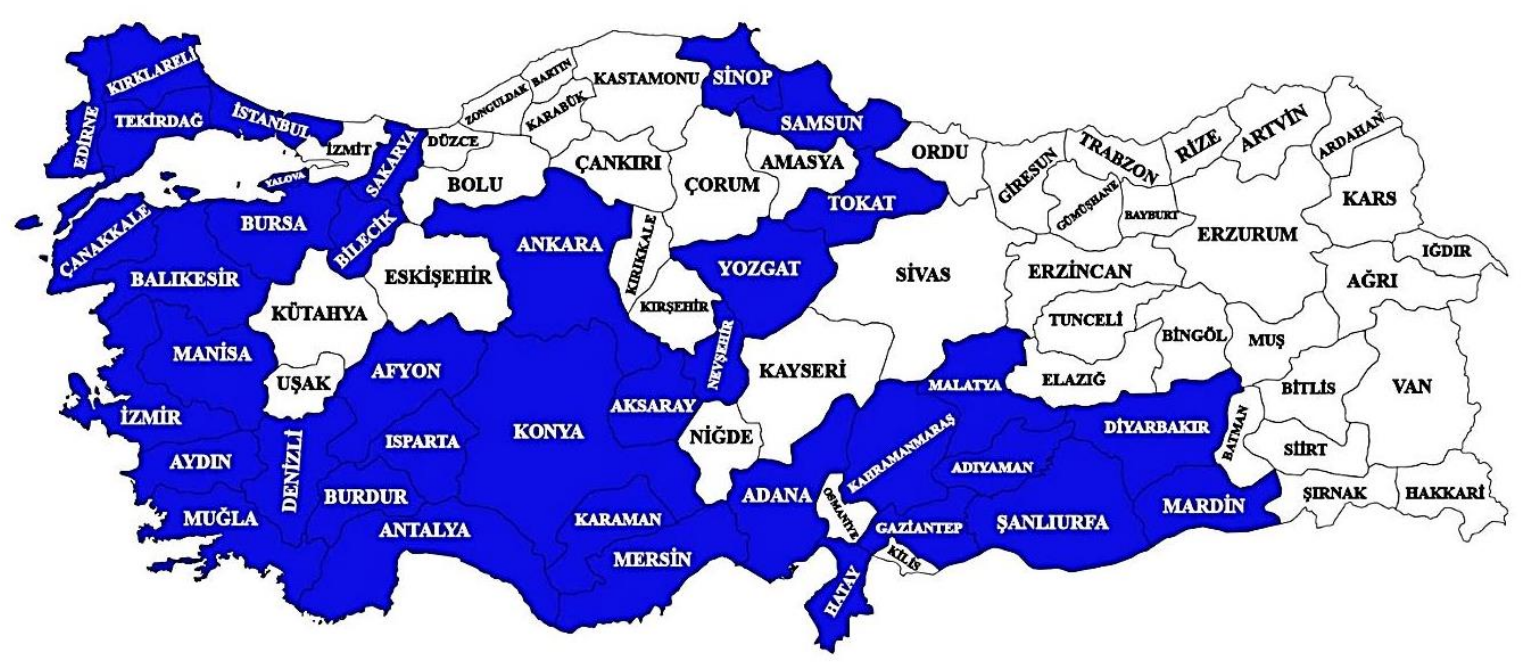

Figure 3. Geographical map showing the distribution of CMV throughout Turkey. İstanbul (Karakurt, 2015); Diyarbakır (Öztürk, 2000; Budak, 2015); Adıyaman (Günay, 2019); Burdur (Çulal Kılıç et al., 2015); Diyarbakır and Mardin (Kızmaz et al., 2016), Tekirdag, Edirne and Kırklareli (Yılmaz, 2014; Köklü and Yılmaz, 2006); Gaziantep (Ozaslan et al., 2006), Şanlıurfa (Ünlü and Güldür, 2004), Yozgat, Nevşehir, Aksaray, Karaman (Yeşil, 2019; Yeşil, 2020; Yeşil, 2018; Yeşil and Ertunç, 2013), Malatya (Örs, 2018), Ankara and Antalya (Dursunoğlu, 2003; Topkaya et al., 2014; Koç and Fidan, 2017); Adana, İçel, İzmir, Manisa, Afyon, Konya, Aydın, Balıkesir, Muğla, Hatay (Yılmaz et al., 1992; Yeşil, 2014; Kaya and Erkan, 2011; Fidan, 1995; Güllü and Çalı, 1994), Sinop (Şevik and Balkaya, 2015), Tokat (Korkmaz et al., 2018), Kahramanmaraş (Buzkan and Yüzer, 2009), Denizli (Özdemir and Erilmez, 2007), Bursa, Bilecik, Çanakkale, Sakarya, Yalova, İstanbul (Uzunoğulları and Gümüş, 2015), Samsun (Sevik, 2017)

Like CMV, WMV is one of the main viruses of cucurbits. With the addition of Uşak (Dikici, 2019) and Van (Usta et al., 2018) to the map below, it is infectious for economically important cucurbits such as pumpkin, watermelon, melon, squash, cucumber (Keçe, 2012; Altınay, 2017; Sevik and Arli-Sokmen, 2003; Yeşil, 2018). Sequence characterizations showed that the sequence similarity ratios of the all isolates from Bingöl ranged from $75.20 \%$ to $94.69 \%$ compared to other sequences in different locations of the world. The Bingöl WMV isolates shared sequence consensus between 91.27- 98.88\% with other isolates, whereas Bingöl CMV isolates shared sequence consensus between 75.20- 94.69\% with other isolates. Sequence homology was determined as 99.84\% for CMV and $99.88 \%$ for WMV when compared between them. The consensus trees created with identical sequences of same isolates from different origin clearly determined the phylogenetic location of the isolates in this study. The CP sequences of the Bingöl isolates were analyzed with the other previously defined viral isolates. CMV and WMV isolates showed the highest sequence similarity among themselves. The molecular analysis of the CMV-CP gene revealed nucleotide homology up to $75.20-94.69 \%$ with those of the infected plants. Both CMV isolates (MT361015 and MT361016) exhibited the highest homology with Chinese isolate (KJ746022) and the lowest with Indian isolate (AJ585086). The CP sequences of Bingöl WMV isolates (MT413451 and 437295) showed sequence similarities ranging from $91.27 \%$ to $98.88 \%$ compared to sequences from different parts of the world. The two isolates displayed the highest phylogenetic affinity with the Chilean isolate and the lowest with the Chinese isolate. Furthermore, the phylogenetic dendrogram backed up the sequence analysis results, revealed three main clusters (subgroup IA, IB, II) for CMV and two clusters for WMV. As shown in Fig 3, Bingöl CMV isolates were clustered with CMV subgroup IB isolates from different regions (Turkey, India, Thailand, and China), indicating that 
they are in CMV subgroup IB. Bingöl WMV isolates were clustered with China-watermelon and Francemelon and zucchini isolates within the Group II (Fig 4). It should be noted that WMV-Group I is similar to WMV-Group II, which includes WMV members infecting different cucurbits such as zucchini, snake gourd, and melon from different countries. In other words, as seen in Fig 4, it can be suggested that the emergence of clearly two groups does not depend on the region nor the host. This situation may possibly be due to insertion, substitution, or deletion in the $\mathrm{cp}$ gene as a result of ongoing genetic variations of the virus, with a wide range sequence similarity rate (91.27-98.88\%) (Vallejos et al., 2006).

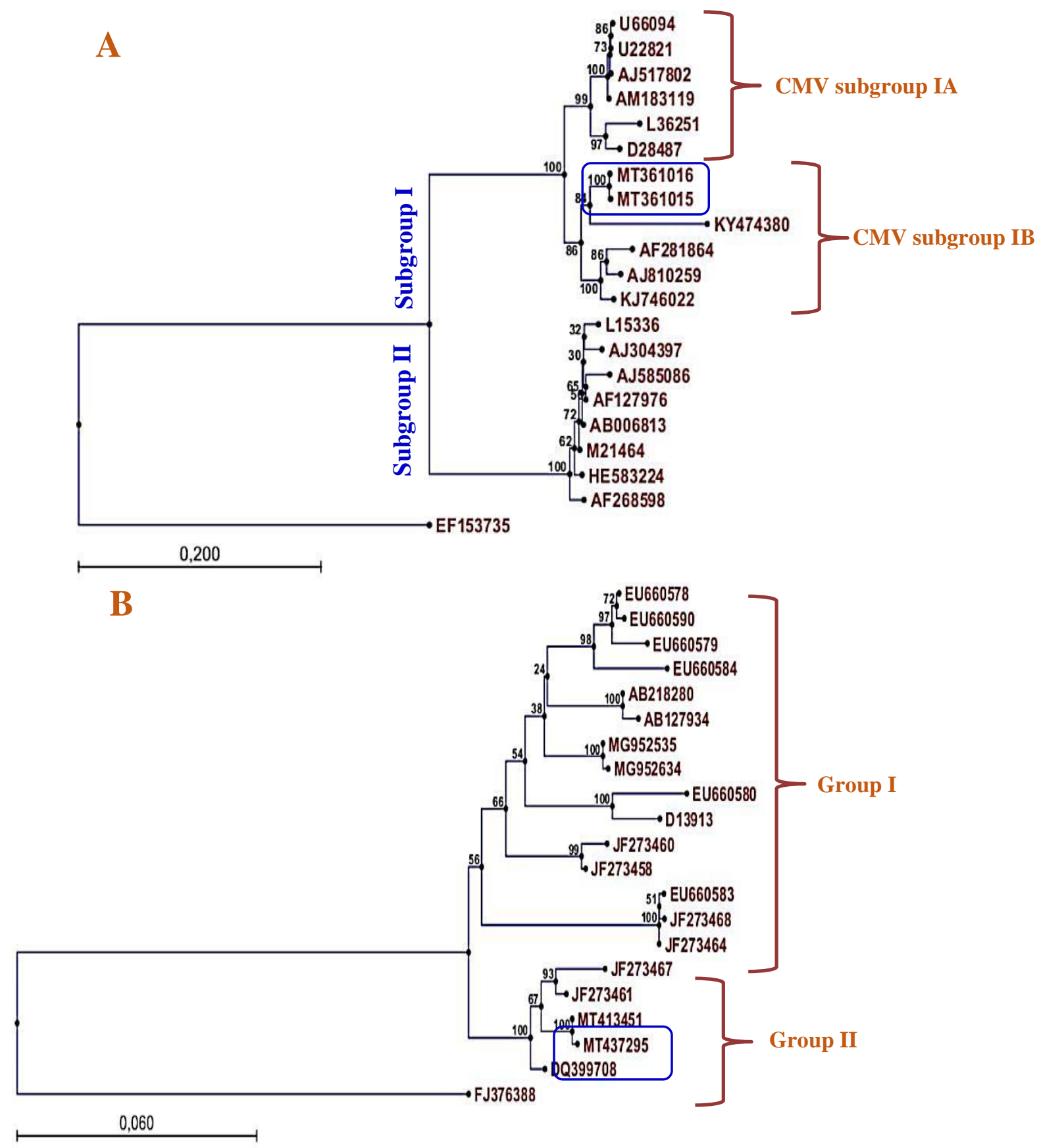

Figure 4. Phylogenetic dendrogram obtained by the NJM using CLC Main Workbench software of CP gene sequences from CMV isolates $(A)$ and WMV (B) in various hosts. Bingöl isolates are shown in a circle

Although there are opportunities for chemical control against fungal and bacterial diseases, there is no such option against viral pathogens. Therefore, protective methods are commonly preferred against plant viral diseases. WMV and CMV are transmitted non-persistent and mechanically with different species of the Aphididae family and lead to intense epidemics 
(Lecoq and Desbiez, 2012). Weed populations both in and around the fields are also the primary infection source for the next year as they are important hosts of viruses. Therefore, weed control and vector struggle are critical to prevent future outbreaks.

\section{Conclusion}

In this study, viral infections in melon plants were examined using DNA-based methods. Our outputs undoubtedly verified that the CMV and WMV were available in Bingöl province of Turkey. Therefore, efforts are required to keep away from the spread of both viruses into Bingöl and adjacent provinces. The two CP sequences are very closely related to the sequences of distinct isolates of the world in varying percentages, indicating genomic stability in the pathogens.

Conflict of Interest Statement: The manuscript's authors declare that, they do not have any conflict of interest.

\section{Researchers' Contribution Rate}

Statement Summary: The authors declare that, they have contributed equally to the manuscript.

\section{References}

Abdalla, O., Bruton, B.D., Fish, W.W. and Ali, A. 2012. First Confirmed Report of Tobacco ringspot virus in Cucurbits Crops in Oklahoma. Plant Disease, 96: 1705.

Aguilár-Ríos, R. and Lozoya-Saldaña, H. 1994. Virus diseases of cucurbits in the state of Morelos. Revista Mexicana de Fitopatología, 12(1): 11-13.

Alonso-Prados, L.J., Luis-Arteage, M., Alvarez, J.M., Moriones, E., Batlle, A., Lavina, A., GarciaArenal, F. and Fraile, A. 2003. Epidemics of Aphid-transmitted Viruses in Melon Crops in Spain. European Journal of Plant Pathology, 109: 129-138.

Al-Saleh, M.A. and Al-Shahwan I.M. 1997. Viruses infecting cucurbits in Riyadh, Gassim and Hail regions of Saudi Arabia. Arab Gulf Journal of Scientific Research, 15(1): 223254.

Altınay, N. 2017. Tekirdağ ilinde bazı kabakgil türlerinde virüs infeksiyonlarının belirlenmesi. Namık Kemal Üniversitesi. Fen Bilimleri Enstitüsü. Bitki Koruma Anabilim Dalı. Yüsek Lisans Tezi. Tekirdağ. $73 s$.
Andres, T.C. 2004. Web site for the plant family Cucurbitaceae \& home of The Cucurbit Network. http://www.cucurbit.org.

Ayo-John, E.I., Olorunmaiye, P.M., Odedara, O.O., Dada, O.B., Abiola, K.O. and Oladokun, J.O. 2014. Assessment of field-grown cucurbit crops and weeds within farms in SouthWest Nigeria for viral diseases. AcademicPres, Cluj-Napoca, Romania, Notulae Scientia Biologicae, 6(3): 321-325.

Beler, Ö. and Açıkgöz, S. 2005. Ege ve Marmara Bölgelerindeki zeytin fidanlıkları ve ağaçlarında görülen bazı virüs hastalıklarının ELISA testi ile saptanması. ADÜ Ziraat Fakültesi Dergisi, 2 (1): 79-84.

Brunt, A., Crdotree, K., Dallwitz, M., Gibbs, A. and Watson, L. 1996. Virus of Plants. Descriptions and lists from the VIDE database. S CAB International University Press, 477-478.

Budak, E. 2015. Diyarbakır İli ve İlçelerinde Üretilen Kabakgillerdeki Viral Etmenlerin Tanılanması ve Yaygınlıklarının Belirlenmesi. Harran Üniversitesi. Fen Bilimleri Enstitüsü. Bitki Koruma Anabilim Dalı. Yüksek Lisans Tezi. 50S.

Buzkan, N. and Yüzer, D. 2009. Molecular detection of seed-borne viruses in Kahramanmaraş red peppers. Alatarım, 8(1): 1-7.

Coutts, B.A. and Jones R.A.C. 2005. Incidence and distribution of viruses infecting cucurbit crops in the Northern Territory and Western Australia. Australian Journal of Agricultural Research, 56(8): 847-858.

Coutts, B.A., Kehoe, M.A. and Jones, R.A.C. 2011 a. Minimising losses caused by Zucchini yellow mosaic virus in vegetable cucurbit crops in tropical, sub-tropical and Mediterranean environments through cultural methods and host resistance. Virus Research, 159: 141-160.

Çat, A., Yardımcı, N. and Kılıç, H.Ç. 2016. Antalya İli ve İlçelerindeki Örtüaltı Hıyar (Cucumis sativus L.) ve Kabak (Cucurbita pepo L.) Üretim Alanlarında Viral Etmenlerin Saptanması. Süleyman Demirel Üniversitesi Fen Bilimleri Enstitüsü Dergisi. 1: 129-132.

Çulal Kılıç, H. and Yardımcı, N. 2012. Burdur Çine Ovası Fasulye Alanlarında Hıyar Mozaik Virüsü. Mehmet Akif Ersoy Üniversitesi Fen Bilimleri Enstitüsü Dergisi, 3 (2): 12-15.

Çulal Kılıç, H., Yardımcı, N., Toplu, S., and Konu A. 2015. Cucumber mosaic virus and Pepper mild mottle virus in pepper growing areas in Burdur Province, Turkey. International 
Journal of Scientific and Technological Research, 1: 1.

Delmiglio, C. and Pearson M.N. 2006. Effect sandincidence of Cucumber mosaic virus, Watermelon mosaic virus and Zucchini yellow mosaic virus in New Zealand's only native cucurbit, Sicyos australis. Australasian Plant Pathology, 35: 29-35.

Demski, J.W. and Chalkley, J.H. 1972. "Effect of Watermelon mosaic virus on Yield and Marketability of Summer Squash" Plant Disease Report, 56: 147-50.

Desbiez, C., Costa, C., Wipf-Scheibel, C., Girard, M. and Lecoq, H. 2007. Serological and molecular variability of Watermelon mosaic virus (genus Potyvirus). Archives of Virology, 152: 775-781.

Dikici, S. 2019. Uşak ilinde bazı kabakgillerde karpuz mozaik virüsü (WMV)'nün serolojik yöntemle belirlenmesi ve biyolojik indeksleme çalışmaları. Uşak Üniversitesi. Fen Bilimleri Enstitüsü. Yüksek Lisans Tezi. Tarım Bilimleri Anabilim Dalı. 102s.

Doolittle, S.P. 1916. A new infectious mosaic disease of cucumber. Phytopathology 6:145-147.

Ergün, M., Semih, E. and Paylan, I.C. 2013. Cucumber mosaic virus in globe artichoke in Turkey. Canadian Journal of Plant Pathology, 35 (4): 514-517.

Erkan, S., Gümüş, M. and Paylan, i.C., Duman İ., Ergün M. 2013. İzmir ili ve çevresindeki bazı kışlık sebzelerde görülen viral etmenlerin saptanması. Ege Üniversitesi Ziraat Fakültesi Dergisi, 50 (3): 311-322.

FAO, 2018.

http://www.fao.org/faostat/en/\#data/QC(Erişim

Tarihi, 29 Ağustos 2018).

Fernandes, F.F. Valverde, R.A. and Black, L.L. 1991. Viruses infecting Cucurbit Crops in Louisiana. Plant Disease, 75: 431.

Fidan, Ü. 1995. Virus diseases of vegetables in greenhouses in İzmir and Muğla. Journal of Turkish Phytopathology, 24(1): 7-14.

Foissac, L., Gentit, P., Svanetia-Dumas, L., Dulucq, M. J. and Candresse, T. 2001. Polyvalent detection of fruit tree tricho, capillo, and foveaviruses by nested RT-PCR using degenerated and inosine-containing primers (PDO RT-PCR). Acta Horticulturae, 550: 37-43.

Fujisawa, I., Anang, S.J., Shen, Y.S. and Zhou, A.J. 1990. Identification of virus diseases affecting some vegetable crops in west Malaysia and the southern part of China. Tropical Agriculture Research Series, 23: 218-228.
Gibbs, A.J., Mackenzie, A.M., Wel, K.J. and Gibbs, M.J. 2008. The potyviruses of Australia. Archives of Virology, 153: 1411-1420.

Gökdağ, S., Karanfil, A. and Korkmaz, S. 2016. Çanakkale ili ıspanak alanlarındaki Şalgam mozaik virüsü ve Hıyar mozaik virüsü varlığının belirlenmesi. Bahçe, özel sayı (cilt II). 166-170.

Güllü, M. and Çalı, S. 1994. Doğu Akdeniz Bölgesi Örtü altı Sebze Alanlarında Görülen Virüs Hastalıklarının Belirlenmesi Üzerine Araştırmalar. Bitki Koruma Bülteni, 34 (34): 79.

Gümüş, M. Erkan, S. and Tok, S., 2004. Bazı Kabakgil Türlerinin Tohumlarındaki Viral Etmenlerin Saptanması Üzerinde Araştırmalar. Ege Üniversitesi Ziraat Fakültesi Dergisi, 41 (1): 49-56.

Günay, A. 2019. Adıyaman İli Tütün Üretim Alanlarındaki Bazı Tütün Virüslerinin Multipleks RT-PCR Yöntemi İle Araştırılması Ve Bazı Virüs İzolatlarının Moleküler Karakterizasyonu. Van Yüzüncü Yıl Üniversitesi. Fen Bilimleri Enstitüsü. Yüksek Lisans Tezi. Bitki Koruma Anabilim Dalı. Van. 63s.

Günay, A. 1993. Özel Sebze Yetiştiriciliği. A.Ü. Ziraat Fakültesi, Ankara, 117s.

Güngör, M., Uzunbacak, H., Kutluk-Yilmaz, N.D. and Şevik, M.A. 2017. Samsun ili ıspanak üretim alanlarında enfeksiyon oluşturan virüslerin belirlenmesi. Anadolu Journal of Agricultural Sciences, 32: 164-168.

Hseu, S.H, Huang, C.H, Chang, C.A, Yang, W.Z, Chang, Y.M. and Hsiao, C.H. 1987. The occurrence of five viruses in six cucurbits in Taiwan. Plant Protection Bulletin, Taiwan, 29(3): 233-244.

Ibaba, J.D, Laing, M.D. and Gubba, A. 2015. Incidence and phylogeny of viruses infecting cucurbit crops in KwaZulu-Natal, Republic of South Africa. Crop Protection, 75: 46- 54.

Jossey, S. and Babadoost, M. 2008.Occurrence and Distribution of Pumpkin and Squash Viruses in Illinois. Plant Disease, 92(1):6168.

Karakurt, M.Y. 2015. İstanbul İlinde Karpuz Ekim Alanlarında Cucumber mosaic virus (CMV) Ve Zucchini Yellow Mosaic Virus (ZYMV)'nin Yaygınlıklarının Araştırılması. Namık Kemal Üniversitesi. Fen Bilimleri Enstitüsü. Yüksek Lisans Tezi. Bitki Koruma Anabilim Dalı. 54s.

Karamanlı, A. and Kamberoğlu, M.A. 2010. Survey of Cucumber mosaic virus (CMV) and Zucchini Yellow Mosaic Virus (ZYMV) in 
Turkish Republic of Northern Cyprus in Cucurbits Growth Fields. Ç.Ü. Fen Bilimleri Enstitüsü, Cilt: 22-23.

Karanfil, A. and Korkmaz, S. 2017. Çanakkale ili börülce üretim alanlarında Hıyar mozaik virüsü (Cucumber mosaic virus; CMV)'nün tespiti ve kılıf protein genine göre moleküler karakterizasyonu. Bitki Koruma Bülteni, 57(3): 293-304.

Karanfil, A., Soylu, B. and Korkmaz S. 2016. Çanakkale ili ve ilçelerindeki soğanlı süs bitkilerinde Hıyar mozaik virüsü enfeksiyonunun serolojik ve moleküler yöntemler ile araştırılması. Trakya University Journal of Natural Sciences, 17 (2): 105-110.

Katul, L. and Makkouk, K.M. 1987. Occurrence and serological relatedness of five cucurbit potyviruses in Lebanon and Syria. Phytopathologia Mediterranea, 26(1): 3642.

Kaya, A., and Erkan, S. 2011. İzmir, Aydın, Manisa ve Balıkesir illerinde Üretilen Kabakgillerdeki Viral Etmenlerin Tanılanması ve Yaygınlıklarının Belirlenmesi. Bitki Koruma Bülteni, 51 (4): 387-405.

Kızmaz, M.Z., Sağır, A. and Baloğlı, S. 2016. Diyarbakır ve Mardin IIlleri Kabakgil Üretim Alanlarında Görülen Viral Hastalıkların Yaygınlıklarının ve Etmenlerinin Belirlenmesi. Ege Üniversitesi Ziraat Fakültesi Dergisi, 53 (4): 397-406.

Ko, S.J., Lee, Y.H., Cho, M.S., Park, J.W., Choi, H.S., Lim, G.C. and Kim, K.H. 2007. The incidence of virus diseases on melon in Jeonnam Province during 2000- 2002. Plant Pathology Journal, 23(3): 215-218.

Korkmaz, F., Topkaya, Ş. and Yanar Y. 2018. Tokat İli Kabakgil Üretim Alanlarında Enfeksiyon Oluşturan Virüslerin Belirlenmesi. Gaziosmanpasa Journal of Scientific Research, 7(2): 46-56.

Kosaka, Y., and Fukunishi, T. 1997. Multiple Inoculation with Three Attemuated Viruses for the Control of Cucumber Virus Diseases. Plant Disease, 81 (7): 733- 738.

Köklü, G., and Yilmaz, Ö. 2006. Occurrence of cucurbit viruses on field-grown melon and watermelon in the Thrace region of Turkey. Phytoprotection, 87 (3): 123-130.

Kwak, H.R., Kim, J.S., Cho, J.D., Lee, J.H., Kim, T.S., Kim, M.K. and Choi H.S. 2015. Characterization of Melon necrotic spot virus Occurring on Watermelon in Korea. Plant Pathology Journal, 31(4): 379-387.
Lecoq, H., and Desbiez, C. 2012. Virus of cucurbit crops in the Mediterranean Region: an ever-changing picture. In: Loebenstein, G., Lecoq, H. (Eds.), Viruses and Virus Diseases of Vegetables in the Mediterranean Basin. Adv. Virus Research, 84: 67-126.

Lot, H. and Kaper, J.M. 1976. Further Studies on the RNA Component Distributon Among the nucleoproteins of Cucumber mosaic virus. Virology, 74: 223-226.

Massumi, H., Samei, A., Pour, A.H, Shaabanian, M, and Rahimian H. 2007. Occurrence, distribution, and relative incidence of seven viruses infecting greenhousegrown cucurbits in Iran. Plant Disease, 91(2): 159-163.

Mnari-Hattab, M., Jebari, H., and Zouba, A. 2008. Identification and distribution of viruses responsible for mosaic diseases affecting cucurbits in Tunisia. Bulletin OEPP/EPPO Bulletin, 38(3): 497-506.

Nayar, N.M. and Singh R. 1998. Taxonomy, distribution and ethnobotanical uses in Cucurbits (N.M. Nayar, and T.A. More, eds.). Science Publishers, Inc., U.S.A. pp 118.

Nematollahi, S., Haghtaghi, E., Koolivand, D. and Hajizadeh M. Molecular detection of Cucumber green mottle mosaic virus variants from cucurbits fields in Iran. Archives of Phytopathology and Plant Protection. 47 (11): 1303- 1310.

Ozaslan, M., Berna, B., Aytekin, T. and Siğırcı, Z. 2006. Identification of Pepper Viruses by Das-elisa Assays in Gaziantep-Turkey. Plant Pathology Journal, 5(1): 11-14.

Örs, F. 2018. Malatya ili Kavun Ekiliş Alanlarında Görülen Bazı Önemli Virüs Hastalıklarının Moleküler Yöntemlerle Araştırılması ve Karakterizasyonu. İnönü Üniversitesi. Fen Bilimleri Enstitüsü. Yüksek Lisans Tezi. Bitki Koruma Anabilim Dalı. Malatya. 39s.

Özdemir, S., and Erilmez, S. 2007. Denizli ilinde yetiştirilen biber, patlıcan ve marul üretim alanlarında bazı viral etmenlerin Saptanması. Türkiye II. Bitki Koruma Kongresi Bildirileri.27-29 Ağustos Isparta. $114 \mathrm{~s}$.

Öztürk, S. 2000. Diyarbakır ve illçelerinde Karpuzlarda Görülen Virüs Hastalıklarının Surveyi. Çukurova Üniversitesi Fen Bilimleri Enstitüsü, Bitki Koruma Anabilim Dalı, Adana, 58s.

Palukaitis, P., and Garcia-Arenal, F. 2003. Cucumber mosaic virus, Description of Plant Viruses, No. 400. 
http://www.dpvweb.net/dpv/showdpv.ph p?dpvno=400, Accessed date: 28 December 2017.

Palukaitis, P., Roossinck, M.J., Dietzgen, R.G. and Francki, R.I.B. 1992. Cucumber mosaic virus. Advances in Virus Research, 41: 281348.

Price, W.C. 1934. Isolation and study of some yellow strains of cucumber mosaic. Phytopathology, 24: 743-761.

Purcifull, D.E. and Hiebert E. 1979. Serological distinction of Watermelon mosaic virus isolates. Phytopathology, 69: 112-116.

Purcifull, D.E. Adlerz, W.C., Simone, G.W., Hieberth, E. and Christie, S.R. 1984. Serological Relationships and Partial Characterization of Zucchini Yellow Mosaic Virus Isolated Form Squash in Florida. Plant Disease, 68: 230- 233.

Raccah, B. 1999. Epidemiology and control of cucurbit viruses in Israel. 1. Israeli- Turkish Workshop "Detection of virus diseases by advanced techniques and control", 22-29. August 1999, Adana, Turkey. 46-56.

Robinson, R.W. and Deckers-Walters, D.S. (eds.). 1997. Cucurbits, CAB International, Wallingford, UK. ISBN: 0851991335.

Rubies-Autonell, C., Ballante, M., and Turina, M. 1996. Viral infections in melon crops of centralnorthern Italy. Informatore Fitopatologico, 46(7/8): 6-10.

Sertkaya, G. 2015. Hatay ili marul ve Ispanak alanlarında bazı virüslerin araştırılması. Mustafa Kemal Üniversitesi, Ziraat Fakültesi Dergisi, 20 (1): 7-12.

Sevik, M.A. 2012. Natural occurrence of Cucumber mosaic virus infecting water mint (Mentha aquatica) in Antalya and Konya, Turkey. Acta Botanica Croatica, 71 (1): 187-193.

Sevik, M.A. and Akcura C. 2011. Occurrence of Cucumber mosaic virus Infecting Parsley (Petroselinum crispum) in Turkey. Notulae Botanicae Horti Agrobotanici Cluj-Napoca, 39(1): 30-33.

Sevik, MA. 2017. Natural occurrence of Cucumber mosaic virus infecting broccoli in Turkey. Virus disease. 28(2): 218-219.

Sevik, M.A. and Arli-Sokmen, M. 2003. Viruses infecting cucurbits in Samsun, Turkey. Plant Disease, 87: 341-344.

Sharifi, M., Massumi, H., Heydarnejad, J. Pour AH. and Shaabanian M., Rahimian. 2008. Analysis of the biological and molecular variability of Watermelon mosaic virus isolates from Iran. Virus Genes. 37: 304313.
Silveira, L.M., Queiroz, M.A, Lima, J.A.A., Nascimento, A.K.Q. and Lima Neto I.S. 2009. Serological survey of virus in cucurbit species in the Lower Middle São Francisco River Basin, Brazil. Tropical Plant Pathology, 34(2): 123-126.

Şensoy, S. 2005. Türkiye Kavunlarındaki Genetik Varyasyonun ve Fusarium Solgunluğuna Dayanıklılığın Fenotipik ve Moleküler Yöntemlerle Araştırılması. Yüzüncü Yıl Üniversitesi. Fen Bilimleri Enstitüsü. Bahçe Bitkileri Ana Bilim Dalı. Doktora Tezi. 164s. Van.

Şevik, MA. and Balkaya, A. 2015. Samsun, Sinop ve Bolu illerindeki Bal Kabağı (Cucurbita Moschata Duch) Popülasyonlarına Ait Tohum Örneklerinde Virüslerin Tanılanması ve Bulunma Durumlarının Belirlenmesi. 32(3): 70-77.

Tobias, I. and Tulipan, M. 2002. Results of virological assay on cucurbits in 2001. Növényvédelem. 38(1): 23-27.

Tobias, I., Szabo, B., Salanki, K., Sari, L., Kuhlmann, H. and Palkovics, L. 2008. Seed borne transmission of Zucchini yellow mosaic virus and Cucumber mosaic virus in Styrian Hulless group of Cucurbita pepo, in: M. Pitrat (Ed.), Proceedings of the IX EUCARPA Meeting of Genetics and Plant Breeding of Cucurbitaceae, INRA, Avignon, France, pp189-197.

Tomassoli, L., Tiberini, A. and Meneghini M. 2009. Zucchini Yellow Fleck Virus is an Emergent Virus on Melon in Sicily (Italy). Journal of Phytopathology, 158(4):314-316.

Trkulja, V., Kovačić, D., Ćurković, B., Vučurović, A., Stanković, I., Bulajić, A. and Krstić B. 2013. First report of Cucumber mosaic virus on melon in Bosnia and Herzegovina. Plant Disease, 97(8): 1124-1125.

Usta, M., Güller, A., Sipahioğlu H.M. 2018. Molecular Characterization of Coat Protein Gene of Two Watermelon mosaic potyvirus Isolates Infecting Muskmelon at Van Province (Turkey). 1. International GAP Agriculture \& Livestock Congress. 2527 April 2018 - Şanlıurfa/Turkey.

Uzunoğulları, N. and Gümüş, M. 2015. Marmara Bölgesi'nde bazı kültür bitkilerinde doğal enfeksiyona neden olan hıyar mozaik virüsü (Cucumber mosaic virus, CMV)'nün Tespiti. Trakya University Journal of Natural Sciences, 16(1): 9-15.

Ünlü, S, and Güldür, M.E. 2004. Şanlıurfa İlinde Biberlerde Zararlı Olan Hıyar Mozayik Virüsü (CMV)'nün ELISA Yöntemiyle 
Saptanması. HUBAK I. Bilimsel Araştırmalar Sempozyumu, Şanlıurfa. 45s.

Vallejos, C.E., Astua-Monge, G., Jones, V., Plyler, T.R., Sakiyama, N.S. and Mackenzie, S.A. 2006. Genetic and molecular characterization of the I locus of Phaseolus vulgaris. Genetics, 172, 1229-1242.

Van Regenmortel, M.H.V., Fauquet, C.M., Bishop, D.H.L., Carstens, E.B., Estes, M.K., Lemon, S.M., Maniloff, J., Mayo, M.A., McGeoch, D.J., Pringle, C.R. and Wickner, R.B. 2000. Family Potyviridae. In: Virus Taxonomy, Seventh Report of the International Committee on Taxonomy of Viruses, pp 703-724. Academic Press, San Diego, USA.

Webb, R.E. and Scott H.A. 1965. Isolation and identification of Watermelon mosaic virus 1 and 2. Phytopathology, 55: 895-900.

Yamaji, Y., Maejima, K., Komatsu, K., Shiraishi, T., Okano, Y., Himeno, M., Sugawara, K., Neriya, Y., Minato, N., Miura, C., Hashimoto, M. and Namba, S. 2012. Lectin-Mediated Resistance Impairs Plant Virus Infection at the Cellular Level. The Plant Cell. 24: 778- 793.

Yeh, S.D., Gonsalves, D. and Provvidenti, R. 1984. Comparative studies on host range and serology of Papaya ringspot virus and Watermelon mosaic virus 1. Phytopathology, 74: 1081-1085.

Yeşil, S. 2014. Virus Diseases of Edible Seed Squash (Cucurbita pepo L.) in Konya province. Fifth International Scientific Agricultural Symposium. Agrosym 2014“.
Yeşil, S. 2018. Some Virus Diseases of Edible Seed Squash (Cucurbita pepo L.) in Aksaray Province, Turkey. Yuzuncu Yil University Journal of Agricultural Sciences. 29 (Special Issue): 63-71.

Yeşil, 2020. Detection of Some Virus Diseases of Edible Seed Squash (Cucurbita pepo L.) in Nevşehir Province, Turkey. Selcuk Journal of Agriculture and Food Sciences, 34 (1): 49-56.

Yeşil, S. 2019. Detection of Viruses on Edible Seed Squash (Cucurbita pepo L.) in Yozgat Province, Turkey. Journal of the Institute of Science and Technology, 9(3): 12121219.

Yılmaz, E. 2014. Edirne İli Sebze Üretim Alanlarındaki Virüs Hastalıklarının Saptanması Üzerine Araştırmalar. Namık Kemal Üniversitesi. Yüksek Lisans Tezi. Fen Bilimleri Enstitüsü. Bitki Koruma Anabilim Dalı. 45s.

Yılmaz, M.A., Lecoq, H., Abak, K., Baloğlu, S. and Sarı N. 1992. Türkiye'de Kabakgil Sebze Türlerinde Zarar Yapan Virüsler. Türkiye 1. Ulusal Bahçe Bitkileri Kongresi. Ege Üniversitesi Ziraat Fakültesi, Bornova, İzmir, 439-442.

Zitter, T.A. Hopkins, D.L. and Thomas, C.E. 1996. Compendium of Cucurbit Diseases. The American Phytopathological Society Aps Press, St. Paulk, Minesota, 87p. 